\title{
SUBRAYAR Y NARRAR, MIENTRAS RESPIRAMOS
}

Carlos Skliar ${ }^{1}$

1 Doctor en Fonología con estudios de posdoctorado en Educación. Investigador principal del Instituto de Investigaciones Sociales de América Latina (IICSAL), Flacso-Conicet. Miembro del PEN (Poetas, Ensayistas, Narradores), Argentina. Correo electrónico: skliar@flacso.org.ar ORCID: https://orcid.org/0000-0002-6360-6259

Cómo citar: Skliar, C. (2020). Subrayar y narrar mientras respiramos. Enunciación, 25(2, separata), V-VIII. https://doi.org/10.14483/22486798.17013 
$\mathrm{S}$ i las vidas en singular-plural fueran apreciadas como textos en estado permanente de escritura, aclaraciones de uno mismo y de otros, elaboraciones y reelaboraciones de obras mínimas siempre precarias y siempre provisorias, los modos de subrayar y subrayarse pueden transformarse en la materialidad de lo inmanente y trascendente de hacer una vida y estar en el mundo.

El trazado de una línea que indica la atracción hacia una palabra, hacia un fragmento -ese lápiz grueso o fino que se ve impulsado a marcar y remarcar posibles sentidos, la desatención de otros rasgos o trazos-, hace del relato de la vida un ejercicio de posturas e imposturas, de reconcentración y contracción, aquello que se quiere ocultar o disimular y de lo que se desea dar a ver, en fin, un ejercicio interminable de obediencia y desobediencia en relación a la textualidad singular y colectiva.

Ahora bien, la incertidumbre puede ser un estado de mudez absoluta o abrir la escena en la que el lenguaje se desanuda, incontrolable, en todas direcciones; la mudez se siente incapaz de subrayar, todo está en ascuas, todo parece texto escrito sobre el agua inquieta. La verborragia, en cambio, impide la diferenciación, la sutil distinción entre lo esencial y lo superfluo.

Entre el mutismo y el verbo desenfrenado, habría que buscar algún signo de lo sustancial, una versión de un relato del ahora mismo que no se estreche tanto que imposibilite la respiración y, la vez, una cierta cadencia del heme aqui, sin más, que insista en su potencia de narración.

¿Qué subrayar, qué afirmar o dudar y qué separar u olvidar de este texto que está aquí en medio de nuestras vidas, y que no hemos requerido ni deseado, pero que apunta como una flecha envenenada hacia todos, insistentemente? ¿Qué subrayarán ahora mismo, en esta escritura posible e imposible de la pandemia, la ancianidad, la niñez? ¿Los hombres, las mujeres? ¿Los acomodados, los sin cobijo? ¿Las médicas, las enfermeras, los enfermos? ¿Los políticos de ocasión, los solidarios de siempre? ¿Los dueños de los grandes medios de comunicación, la vecina a la que se le ayuda con la comida? ¿Quién, cómo marcará y remarcará las palabras soledad, desgarro, posibilidad, agonía, sobrevida, lectura, comunidad, muerte, incógnita, perplejidad, lucider, provecho, amor, desidia, cuidado?

Las posibilidades son muchas, sobre todo si en vez de obsesionarse con la propia voz se agudizara su parte más entrañable -acallarse, atender, escuchar-y la voz se inclinase en dirección a la conversación y no ya al monólogo. Y al escuchar-que es otro modo de subrayar- el movimiento versionado podría describir el arco entre la proximidad y la lejanía de tres tiempos, su tensión o distensión: la voz, el texto de la vida que era hasta aquí; la voz, el texto de la vida que está siendo; la voz, el texto de la vida que podría ser de aquí en adelante.

En todo ello no hay ninguna técnica, ni método, ni siquiera alguna particularidad o novedad a explicitar; de algún modo siempre ha sido así, siempre la voz y el texto deambulan lúcidos o fantasmales entre el pasado, el presente y el devenir. La diferencia está en que ahora el presente no solo es dubitativo sino, sobre todo, afónico o excesivamente gutural; allí habita el desconcierto y el pasaje entre los tiempos se hace -si lo hiciera- mediante un salto abismal hacia un vacío atolondrado de palabras o un rellano de silencios.

Está claro que los subrayados son, por regla general, coyunturales y epocales, y que las vidas también lo son; como también es bien cierto que pueden ser modos anticoyunturales, contraepocales, o fuera de época. Y esta es una de las probables diferencias entre biografía y ficción, entre testimonio y narración literaria, entre confesión secreta y poesía.

Un subrayado podría ser un gesto de respeto, dejar intacto al autor, o bien un gesto mecánico de dócil persecución a una pista inconducente, o la alabanza de la literalidad; pero además, podría ser una forma de rebelión: trazar una línea 
sobre un espacio ya escrito, darle al texto consagrado otra densidad y otra magnitud, doblegar su sentido sin acatarlo fielmente, crear el propio juego de luces y sombras, rehacer lo escrito, hacer otro texto.

En cierta literatura, las pestes, las epidemias crean escenarios de cofradía y de amor, pequeñas políticas que afloran cuando todo alrededor se desmorona y los individuos deambulan sin ton ni son. El ejemplo florentino de Bocaccio es uno de ellos: "Entonces es cuando se hace mucho más reconocible que en cuanto el opus commune se desintegra en el nivel superior, los hombres solo pueden regenerarse en pequeñas unidades" (Sloterdiijk, 1994, p. 83). I promessi spossi de Manzoni, también lo es: un final feliz, la dicha del amor reencontrado y materializado, a pesar de todo.

La literatura en cuestión ubica el relato en el extremo de un desenlace necesario: al fin, por fin, el final. Pero por su propia razón de ser ese final nunca es concluyente ni da la sensación de pasar de página, como si nada hubiese ocurrido. Por el contrario, la lectura atenta brindará, a la vez, un doble pliegue que mantiene en vilo toda conclusión: el júbilo, la celebración, la alegría porque algo terrible y devastador ha concluido finalmente; la sospecha, el rumor ennegrecido, la intuición cierta de que nada ha concluido de verdad, que todo otra vez está o podría estar a punto de recomenzar:

Oyendo los gritos de alegría que subían de la ciudad, Rieux tenía presente que esta alegría está siempre amenazada. Pues él sabía que esta muchedumbre dichosa ignoraba lo que se puede leer en los libros, que el bacilo de la peste no muere ni desaparece jamás, que puede permanecer durante decenios dormido en los muebles, en la ropa, que espera pacientemente en las alcobas, en las bodegas, en las maletas, los pañuelos y los papeles, y que puede llegar un día en que la peste, para desgracia y enseñanza de los hombres, despierte a sus ratas y las mande a morir en una ciudad dichosa. (Camus, 2005, p. 219)
Mientras la vida se confunde demasiado con su contingencia y su límite: contar historias, porque de eso se trata la vida personal y colectiva, o de ello se trataba hasta hace muy poco tiempo; pero para poder contar historias hay que tener tiempo y hay que tener espacio, ese tiempo y ese espacio que ahora, en esta terca y tensa actualidad, no están a disposición y de los que somos desposeídos.

En otros tiempos, quizá durante el reinado de los abuelos y de la infancia, y en otros espacios, tal vez en sitios alejados de los centros urbanos o en los barrios donde todavía era posible sentarse en el umbral de las casas y en sus patios, contarse historias era sinónimo de hacer la vida, de reelaborarla como bien o mal se pudiera.

La vida como una artesanía narrativa; quienes cuentan historias como artesanos de un mundo quizá mejor, o más amplio, o más largo, o más hondo, o más duradero, o más remoto y, por ello mismo, semejante a una memoria singular y colectiva.

No se trata aquí solamente de una construcción o un género literario específico, ni de técnicas o habilidades consagradas de la lengua, sino de toda narración de cualquiera a cualquiera, de otros hacia otros, y de uno hacia sí mismo; dueña de un lenguaje refinado o balbuceada con monosílabos, verosímil, fantástica o ficcional, extensa o abreviada, precisa o difusa.

Los atributos de una narración abren el juego a una cuestión que podría parecer confusa pero que acaba siendo esencial: la diferencia entre el privilegio del yo que narra y la fragilidad de lo que es suyo o, para mejor decir, la distinción entre la omnisciencia del narrador y la potencia de la búsqueda de lo común en sus intensas variaciones del relato.

Marina Tsvietáieva (2008) recordaba a sus lectores esta sutil diferencia: no se trata de adorar al yo, a la identidad del yo, sino a lo suyo, a aquello que de ese yo se expone en su exterioridad y sale al encuentro de los demás y se abre al devenir de la conversación. 
Como si en la narración de una historia de vida no tuviese ninguna importancia el quién del relato, el cómo es ese quién, su identificación precisa y definitiva, sus virtudes y sus valores, y más bien sea su acción en el mundo la que posibilita el afecto de la atención y de la escucha.

Esta es la diferencia esencial entre la identidad y la intimidad en un relato, en una historia, en un personaje, quienquiera sea. La distinción radical entre mi yo y lo que es mío; mío, no en el sentido de propiedad privada sino en su gestualidad abierta, lo que forman parte de uno en el mismo instante en que se pone sobre la mesa para un banquete común.

Contar lo incontable, para que pueda ser contado; contar con otros, contar con alguien, sentir ese sostén del relato sin el cual el lenguaje y la vida -y el mundo- se caerían abruptamente de las manos: "No estás jodido verdaderamente mientras tengas una buena historia a cuestas y alguien a quien contársela" (Baricco, 2015, pp. 19-20).

No hay tópicos determinados en la narración, no existe ningún canon que pueda prefabricarse o, en todo caso, la narración expuesta en el mundo a través de las voces de las vidas resulta ser interminable, inagotable, inextinguible.

Sin embargo, hoy se ha dejado de narrar, salvo contadas excepciones; se comentan abundantemente imágenes de la lengua que no alcanzan el gemido, el hueso o la metáfora. El efecto inmediato ha desplazado al afecto imperecedero, y basta una imagen propia proyectada en un espejo, tomada casi involuntariamente, casi sin quererlo, ese retrato repetido y sin lenguaje, que solo quiere ganar adhesiones y ocultar los rechazos.

El yo que se cree sabedor de su yo triunfa, es verdad, pero la victoria no solo es lastimosa y efímera, sino adictiva y por momentos enfermiza. Es un yo cuantificado, tan autorreferencial como estrecho y resecado, que se da a ver, pero no ya en su claroscura intimidad, motivado por la satisfacción que ofrecen no otros relatos sino la cantidad de seguidores. Y sus tópicos, que sí siguen un canon, pero que no encuentran variación ni tonalidades y, por tanto, casi nunca dan paso a la narración, es decir, a lo otro y al otro.

Si se pensara en un libro como una historia narrada, contada, comenta Pascal Quignard (2016), su valor no es intrínseco, no vale por sí mismo sino gracias al otro.

Pues habría que contar también lo oscuro, lo opresivo, lo vil, lo que no ha tenido todavía palabras, lo que es puro grito y está en la punta de la lengua. Intentar desmadejar aquello que ha obturado la vida, la ha humillado, dejando un relato a medio hacer y una vida a medio camino.

Para que existan historias, para que puedan ser contadas de verdad, en su duración imprecisa y en un lugar indefinido, es necesario escuchar, y esto quiere decir: prescindir del yo que se anticipa, que ya sabe, que ya conoce, que adivina aburridamente lo que vendrá.

Nada hay más triste que una historia que ha sido abandonada, olvidada. Como si la vida que expresa ese relato pereciera lentamente, descartando de su cuerpo palabras que quizá pudieron ser pronunciadas.

Para que haya una vida es preciso que haya otra vida que le dé sostén, que la escuche, que la acompañe, que le preste atención. Como se pueda, incluso a medio oír, a duras penas, para que valga la pena vivir, mientras respiramos.

\section{Referencias}

Baricco, A. (2015). Novecento. Barcelona: Anagrama.

Camus, A. (2005). La peste. Barcelona: Edhasa.

Quignard, P. (2016). Pequeños tratados. México: Sexto Piso.

Sloterdijk, P. (1994). En el mismo barco. Ensayo sobre la hiperpolítica. Madrid: Siruela.

Tsvietáieva, M. (2008). Confesiones. Vivir en el fuego. Barcelona: Galaxia Gutenberg.

\section{(c) (1) $(9)$}

